\title{
How Do Scale Insects Settle into the Nests of Plant-Ants on Macaranga Myrmecophytes? Dispersal by Wind and Selection by Plant-Ants
}

by

Chihiro Handa ${ }^{1,2}$, Shouhei Ueda ${ }^{3}$, Hirotaka Tanaka ${ }^{4}$, Takao Itino $^{5}$

$\&$ Takao Itioka $^{1}$

\section{ABSTRACT}

This report elucidates the process of settlement by Coccus scale insects into Crematogaster plant-ant nests formed inside the hollow stems of a myrmecophytic species, Macaranga bancana, in a tropical rain forest. We collected wafting scale insect nymphs from the canopy using sticky traps and characterized the DNA sequence of the trapped nymphs. In addition, we experimentally introduced first-instar nymphs of both symbiotic and nonsymbiotic scale insects to $M$. bancana seedlings with newly formed plant-ant colonies. Nymphs of symbiotic species were generally carried by ants into their nests within a few minutes of introduction. Most nymphs of nonsymbiotic species were thrown to the ground by ants. Our results suggest that in Crematogaster-Macaranga myrmecophytism, symbiotic coccids disperse by wind onto host plant seedlings at the nymphal stage, and plant-ants actively carry the nymphs landing on seedlings in to their nests in discrimination from nonsymbiotic scale insects.

Key Words: ant-plant, ant-hemipteran interaction, mutualism, Southeast Asian tropical rain forest, Borneo

\section{INTRODUCTION}

Mutualisms between ants and honeydew-producinghemipterans are sometimes so developed and intensive that both partners have evolved extensive

${ }^{1}$ Graduate School of Human and Environmental Studies, Kyoto University, Sakyo, Kyoto 606-8501, Japan

${ }^{2}$ Corresponding author: E-mail: c.h.chihiro@gmail.com

${ }^{3}$ Institute of Mountain Science, Shinshu University, Asahi 3-1-1, Matsumoto, Nagano 390-8621, Japan ${ }^{4}$ Entomological Laboratory, Faculty of Agriculture, University of the Ryukyus, Okinawa 903-0213, Japan

${ }^{5}$ Department of Biology, Faculty of Science, Shinshu University, Asahi 3-1-1, Matsumoto, Nagano 3908621, Japan 
coadaptations (Way 1963; Buckley 1987). Myrmecophilous hemipterans appear to adapt to associations with ants by modifying their behaviors, body structures, and life cycles (Way 1963; Buckley 1987; Gullan 1997; Gullan \& Kosztarab 1997). Hemipterans that are frequently associated with ants tend to have poorly developed structures for movement and defense against natural enemies (Way 1963; Buckley 1987). Meanwhile, partner ants sometimes have behaviors adapted to the hemipterans. For example, some ants have been reported to not only tend, but also transport, their hemipteran symbionts (Hölldobler \& Wilson 1990). In some species, workers carry symbiotic hemipterans to the appropriate part of the host plants (Way 1963; Maschwitz \& Hänel 1985; Hölldobler \& Wilson 1990; Gullan 1997). In some other species, foundress queens carry symbiotic hemipterans during the nuptial flight and colony foundation (Hölldobler \& Wilson 1990; Klein et al. 1992; Gullan 1997; Gaume et al.2000; Johnson et al. 2001). These transport behaviors are thought to play an important role in ensuring the foundress queens maintain symbioses with hemipterans that can provide the ants with a nutritious food resource in the form of honeydew.

Ant-hemipteran mutualisms are observed in ant nests in some myrmecophytes, plants that provide their partner ants (plant-ants) with nesting spaces (domatia) (Ward 1991; Gullan 1997). In a few cases of mutualism between hemipterans and "plant-ants," i.e., in ant species symbiotic with a myrmecophyte, the foundress queens transport the hemipteran symbionts during the nuptial flight or colony foundation (Klein et al. 1992; Gaume et al.2000). However, how most hemipteran species colonize the nests of their partner plant-ants remains unknown.

Macaranga myrmecophytes (Euphorbiaceae) harbor scale insects of the genus Coccus (Coccidae) inside hollow stems that are occupied by partner plant-ants (Heckroth et al. 1998; Ueda et al. 2008, 2010). Some Macaranga species depend on plant-ants for anti-herbivore defense, and they are thought to be unable to survive without symbiotic plant-ants (Fiala et al. 1989, 1994; Itioka et al.2000; Heil et al. 2001). In addition, symbiotic coccids are considered to benefit the performance of plant-ants (Heckroth et al. 1999; Handa \& Itioka 2011). However, like many symbiotic hemipterans, how coccids disperse and settle into newly founded colonies of their partner plant-ants is not fully known. Coccids have never been previously observed being carried by 
alate foundress queens (Fiala \& Maschwitz 1990; Maschwitz et al. 1996, and Handa \& Itioka personal observation of $>30$ alate plant-ant queens founding new colonies). In addition, coccids have rarely been observed in early-stage nests of plant-ant colonies, even in several Macaranga myrmecophyte species that almost always harbor symbiotic coccids (Fiala \& Maschwitz 1990; Heckroth et al. 1998).

In this study, we aimed to elucidate the process of settlement by coccids into plant-ant nests on Macaranga myrmecophytic species. Many species of scale insects in widespread taxa are known to be wind-dispersed as first-instar nymphs (Washburn \& Washburn 1984; Gullan \& Kosztarab 1997). Therefore, we hypothesized that coccids inhabiting plant-ant nests on Macaranga myrmecophytes might disperse by wind. To test this hypothesis, we used sticky traps in the forest canopy to catch small airborne insects such as dispersing symbiotic coccids of Macaranga myrmecophytes. Next, we experimentally introduced first-instar nymphs of both symbiotic and nonsymbiotic scale insect species onto the surface of Macaranga seedlings and observed the behavior of plant-ant workers in response to each.

\section{MATERIALS AND METHODS}

\section{Study area and Macaranga myrmecophytes}

The study was carried out in Lambir Hills National Park, Sarawak, Malaysia ( $4^{\circ} 2^{\prime} \mathrm{N}, 113^{\circ} 50^{\prime} \mathrm{E}$; 50-200 $\mathrm{m}$ above sea level), which is mainly primary lowland mixed dipterocarp forest. The uppermost canopy layer ranges from 30 to $40 \mathrm{~m}$, with emergent trees penetrating the layer to heights of $>70 \mathrm{~m}$ (Kato et al. 1995). Rainfall and temperature do not follow clear seasonal patterns (Ashton \& Hall 1992; Kato et al. 1995; Roubik et al. 2005).

More than 16 species of Macaranga plants, including at least 10 species of myrmecophytes that can reach $20 \mathrm{~m}$ in height(Davies et al. 1998; Davies 2001), are found around the study site (Itioka 2005). The stems of most Macaranga myrmecophytes species become hollow when seedlings reach approximately $10-20 \mathrm{~cm}$ in height, allowing an alate foundress queen of Crematogaster ant species to settle into the stem and produce workers (Fiala \& Maschwitz 1990). Workers then make exit holes on the exterior surface of stems.

Coccids have rarely been observed inside the nests of plant-ant colonies in the early stage of foundation just after the workers begin to emerge on the 
surface of seedlings (Handa \& Itioka, personal observations on $>200$ seedlings at this stage). First-instar "crawling" nymphs of the superfamily Coccoidea disperse over relatively long distances by wind or walking. Older nymphs and adults, except for alate males, tend to stay at a site or move only short distances (Miller \& Kosztarab 1979; Gullan \& Kosztarab 1997).

Partnerships between Macaranga myrmecophytes and plant-ants are remarkably species-specific (Fiala et al. 1999; Itino et al. 2001). However, partnerships between plant-ants and coccids are not highly species-specific, although several Coccus spp. exclusively inhabit ant nests in Macaranga myrmecophytes (Heckroth et al. 1998; Ueda et al. 2008, 2010).

\section{Capture of wafting coccids}

In January 2008, we selected nine trees of four Macaranga myrmecophytic species (one M. lamellata, one M. trachyphylla, two M. winkleri, and five $M$. beccariana), which ranged from 3 to $10 \mathrm{~m}$ in height, at the Crane site ( 4 ha, $200 \times 200 \mathrm{~m}$ ) where a crane provided access to the canopy (Ozanne et al. 2003; Roubik et al. 2005). To capture small wafting insects, we strung three $6 \times 25 \mathrm{~cm}^{2}$ sheets coated on one side with adhesive (Shimada Co., Higashiomi, Japan) from three lateral branches of each tree. We collected all 27 adhesive sheets after 7 days. We collected 27 suspected coccid insects from eight sheets that were hung from one $M$. trachyphylla, one $M$. winkleri, and three $M$. beccariana trees.

\section{DNA sequencing and phylogenetic analyses}

We extracted DNA from a whole body of each of the 27 wafting insects collected using the DNeasy Blood \& Tissue Kit (Qiagen, Hilden, Germany). A partial cytochrome oxidase I (COI) gene ( $521 \mathrm{bp}$ ) of mitochondrial DNA genome was amplified by polymerase chain reaction (PCR) and sequenced. Methods of PCR, DNA purification, and sequencing followed Ueda et al. (2008). We obtained 16 sequences among 27. In the other 11 samples DNA fragments could not be amplified using PCR. We inferred a molecular phylogeny by adding the sequences to the DNA alignment of COI (Dataset 2) in Ueda et al. (2010), which is thought to cover almost all species of symbiotic coccids associated with Macaranga myrmecophytes.

Maximum likelihood (ML) analysis was performed with PHYML version 2.4.4 (Guindon \& Gascuel 2003). The best-fitting substitution model 
was selected for each data set based on hierarchical likelihood ratio tests (hLRT, Huelsenbeck \& Rannala 1997) using Modeltest version 3.7 (Posada \& Crandall 1998). The GTR+I+G substitution model was used as selected by hLRT in both data sets. Clade support was assessed with 1000 bootstrap pseudoreplications. In addition, Bayesian posterior probabilities and maximum parsimony (MP) bootstrap support were obtained using MrBayes version 3.1.2 (Huelsenbeck \& Ronquist 2001) and PAUP* 4.0b10 (Swofford 2002), respectively. For more details on phylogenetic methods, see Ueda et al. (2008).

\section{Introduction of symbiotic and nonsymbiotic scale insects to plant-ants}

We haphazardly selected one $M$. bancana tree that was approximately 10 $\mathrm{m}$ high and growing in a forest gap. We cut off and dissected a few lateral branches of the tree and collected crawling coccid nymphs from under sessile mature adult coccids in hollow stems. We also collected crawling nymphs of nonsymbiotic scale insect species from five $M$. bancana trees that had no plant-ant workers on the surface. Plant-ant workers on these saplings were thought to have disappeared or become inactive due to accidental causes such as damage by falling trees, large litterfalls, and floods. We found three species of nonsymbiotic scale insects (Coccus sp. nr. celatus, Pseudococcus sp. 1, and Iceryini sp. 1) on leaves and twigs of M. bancana trees. We collected an additional scale insect species (Iceryini sp. 2) from the leaves of one mature non-myrmecophyte $M$. gigantea tree. We observed these four species of scale insects being tended by opportunistic (non-plant-ant) ant species, but they were never found in plant-ant nests.

We collected $M$. bancana seedlings of 10 to $30 \mathrm{~cm}$ height from the forest and planted them in pots in a meshed nursery. We selected 45 vigorous seedlings that had active ant colonies. Plant-ants were seen walking on the plant surface and several exit holes occurred near the ant nest. The plant-ant activities and the density of exit holes were clearly higher around the apical part, compared to the other parts.

We introduced one crawling nymph of either a symbiotic or nonsymbiotic scale insect onto one of the 45 seedlings. For each trial, a crawling nymph was placed on the apical part of the stem surface within $3 \mathrm{~cm}$ of an exit hole. We 
observed the behavior of the nymph and the behavioral responses by plantants. Each seedling was used for one to five introduction trials.

Within 3 min after introduction, most nymphs were contacted by ant workers, and the others entered the nests without any contact with ants. The ants' behaviors after contacting introduced nymphs were categorized into two types: "carrying into nests," in which plant-ants carried nymphs into nests with their mandibles, and "removal," in which they dropped nymphs off the plant.

We observed all exit holes of a target seedling for 3 min after a nymph entered or was carried into a nest. In addition, for 10 individuals of symbiotic species and two individuals of nonsymbiotic species, we checked the ground for nymphs for $15 \mathrm{~min}$ after the nymphs entered a nest. Overall, we obtained observational data for 32 symbiotic coccid nymphs and 73 nonsymbiotic nymphs.

\section{RESULTS}

\section{DNA characterization of wafting scale insects}

All of the sequences obtained from the 16 individuals constituted one haplotype. The monophyly of the clade including these obtained sequences and those belonging to L6 from Ueda et al. (2010), which consists of Macaranga-inhabiting Coccus scale insects, was strongly supported by all of the three methods: ML bootstrapping (100\%), Bayesian posterior probability (100\%), and MP bootstrapping (100\%).

\section{Plant-ants' responses to experimentally introduced scale insect nymphs}

Of the 32 introduced symbiotic coccid nymphs, 30 were directly contacted by plant-ants. Within $30 \mathrm{~s}$ after the first contact of nymphs, plant-ants always grasped nymphs in their mandibles and carried them into hollow stems, except for one case in which a plant-ant dropped the nymph down (Table 1). The other two nymphs walked into nests were not recognized by the plant-ants and entered nests on their own after searching around exit holes. One of these was observed being grasped by an ant just after it entered an exit hole. The proportion of symbiotic nymphs taken into nests was significantly greater than nymphs removed from plants (Table 1 ; binominal test, $p<0.001$ ). Regardless 
Table 1. Behavioral responses of the plant-ants to experimentally introduced first-instar nymphs of symbiotic and nonsymbiotic scale insects on seedlings of Macaranga bancana and the significance probability $(p)$ of binomial tests on the null hypothesis that the two types of behaviors might be randomly adopted.

\begin{tabular}{llcl}
\hline \hline & \multicolumn{3}{c}{ Responses of plant-ants } \\
& Carrying into nests & Removal & $p$ \\
& & & \\
\hline Symbiotic coccids & 29 & 1 & $<0.001$ \\
Nonsymbiotic scale insects & & & \\
Coccus sp. nr. celatus & 0 & 22 & $<0.001$ \\
Pseudococcus sp. 1 & 1 & 22 & $<0.001$ \\
Iceryini sp. 1 & 1 & 12 & 0.003 \\
Iceryini sp. 2 & 0 & 15 & $<0.001$ \\
\hline
\end{tabular}

of the mode of entry, all symbiotic nymphs stayed inside for at least $3 \mathrm{~min}$ and none of the 10 target nymphs were found on the ground 15 min later.

Of the 73 nonsymbiotic scale insects introduced, 71 were removed and the other two were carried into nests. For each of the four nonsymbiotic species, the proportion of removed nymphs was significantly higher than that of nymphs carried into nests (Table 1; binominal test, Coccus sp. nr. celatus: $p<0.001$; Pseudococcus sp. 1: $p<0.001$; Iceryini sp. 1: $p=0.003$; Iceryini sp. $2: p<0.001)$. Seventy percent of the removed nymphs were dropped off the plant within $10 \mathrm{~s}$ after their first contact with plant-ants. The others were carried by plant-ants from $10 \mathrm{~s}$ to $7 \mathrm{~min}$ before eventually being dropped from the plant. One nymph of Pseudococcus sp. 1 and one nymph of Iceryini sp. 1 were carried into nests and stayed inside for more than $3 \mathrm{~min}$, but were then found on the ground within $15 \mathrm{~min}$.

\section{DISCUSSION}

Because no case of foundress queens of plant-ants on Macaranga myrmecophytes carrying their symbiont coccids to new nests had been reported, the symbiont coccids were assumed to disperse independently of their partner plant-ants (Fiala \& Maschwitz 1990; Maschwitz et al. 1996). However, the dispersal of the symbiont coccids has not been empirically studied. This study presents some evidence on details of the dispersal of the symbiont coccids. We collected symbiotic coccid nymphs in the canopy dispersing by wind to host plant seedlings, where plant-ants develop new colonies. First-instar 
coccid nymphs are difficult to identify to species morphologically. DNA sequencing compared with a molecular phylogeny (Ueda et al. 2010) suggested that many of the trapped coccids were in one of the clades known to be symbionts of plant-ants on Macaranga myrmecophytes. Crawlers of these symbiotic coccids have no physical adaptations for flight, so they are believed to disperse passively by wind.

Our experimental introductions of crawling nymphs suggest that in Crematogaster-Macaranga myrmecophytism, plant-ants actively carry winddispersed nymphs of symbiotic coccids into their nests and clearly discriminate against morphologically similar nonsymbiotic nymphs. Crematogaster plant-ants are known to exclude almost all extraneous materials, including those that would be food for the majority of other ants, by carrying them in their mandibles and throwing them off their host plants (Fiala \& Maschwitz 1990; Hashimoto et al. 1997). This habit of plant-ants was confirmed in our experiments; most of the introduced nymphs of non-symbiont scale insects were removed by plant-ants soon after first contact. This indicates that symbiont coccids are among the few organisms not excluded by plant-ants. Symbiont coccid nymphs also seem to be able to enter plant-ant nests by walking into them after alighting on a seedling. In our observations, none of the symbiont coccid nymphs that entered ant nests by either method were excluded by plant-ants, whereas all of the non-symbiont scale insect nymphs were excluded even if they were carried into nests. Thus, plant-ant workers in the Macaranga myrmecophytism appear to actively accept nymphs of only symbiotic coccid species.

Some symbiotic scale insects have been suggested to enter the domatia of myrmecophytes without any help from plant-ants (Wheeler 1921; Bequaert 1922; Moog et al. 2005). To the best of our knowledge, no previous report has described plant-ants actively carrying symbiotic hemipterans into their nests. The active transportation of symbiotic coccids by the plant-ants inhabiting Macaranga myrmecophytes suggests they may have a stronger dependence on their symbiotic coccids than in many other ant-hemipteran interactions, except for ones in which foundress queens transport symbiotic scale insects (Klein et al. 1992; Gullan 1997; Gaume et al. 2000). Positive effects of symbiotic coccids on the growth of plant-ant colonies in Macaranga 
myrmecophytism (Handa \& Itioka 2011) may be associated with the plantants' heavy dependence on coccids.

The limited range of symbiotic hemipteran species of Macaranga plant-ants (Heckroth et al. 1998; Ueda et al. 2008, 2010) can no doubt be maintained by such rejecting behaviors as observed in our system. Selection of scale insects by plant-ants may be adjusted in the evolutionary process on the basis not only of food intake from the honeydew or meat of scale insects but also of the total effects, including herbivory damage caused by the scale insects on the host plants.

\section{ACKNOWLEDGMENTS}

Our study was conducted in accordance with the Memorandum of Understanding signed between the Sarawak Forestry Corporation and the Japan Research Consortium for Tropical Forests in Sarawak in November 2005. We thank J. J. Kendawang, L. Chong, and other staff members of the Forest Research Centre, Sarawak, and Forest Department of Sarawak for providing access to the study site as well as kind assistance. We are also grateful to T. Nakashizuka, M. Ichikawa, N. Yamamura, and S. Sakai for supporting our research activities and A. Yoneyama for assistance in sampling. This work was supported by grants-in-aid from the Japan Society for the Promotion of Science (JSPS) to T. I. (No. 17405006) and to C. H. as a JSPS Fellow and from the Research Institute for Humanity and Nature (project numbers 2-2, D-04).

\section{REFERENCES}

Ashton, P.S. \& P. Hall 1992. Comparisons of structure among mixed dipterocarp forests of north-western Borneo. Journal of Ecology 80: 459-481.

Bequaert, J. 1922. Ants in their diverse relations to the plant world. Bulletin of the American Museum of Natural History 45: 333-584.

Buckley, R.C. 1987. Interactions involving plants, Homoptera, and ants. Annual Review of Ecology and Systematics 18:111-135.

Davies, S.J.2001. Systematics of Macaranga sects. Pachystemon and Pruinosae (Euphorbiaceae). Harvard Papers in Botany 6: 371-448.

Davies, S.J., P.A. Palmiotto, P.S. Ashton, H.S. Lee \& J.V. Lafrankie 1998. Comparative ecology of 11 sympatric species of Macaranga in Borneo: tree distribution in relation to horizontal and vertical resource heterogeneity. Journal of Ecology 86: 662-673. 
Fiala, B. \& U. Maschwitz 1990. Studies on the South East Asian ant-plant association Crematogaster borneensis/Macaranga: adaptations of the ant partner. Insectes Sociaux 37: 212-231.

Fiala, B., U. Maschwitz, T.Y. Pong \& A.J. Helbig 1989. Studies of a South East Asian antplant association: protection of Macaranga trees by Crematogasterborneensis. Oecologia 79: 463-470.

Fiala, B., H. Grunsky, U. Maschwitz \& K.E. Linsenmair 1994. Diversity of ant-plant interactions: protective efficacy in Macaranga species with different degrees of ant association. Oecologia 97: 186-92.

Fiala, B., A.Jakob \& U.Maschwitz 1999. Diversity, evolutionary specialization and geographic distribution of a mutualistic ant-plant complex: Macaranga and Crematogaster in South East Asia. Biological journal of the Linnean Society 66: 305-331.

Gaume, L., D. Matile-Ferrero \& D. McKey 2000. Colony foundation and acquisition of coccoid trophobionts by Aphomomyrmex afer (Formicinae): co-dispersal of queens and phoretic mealybugs in an ant-plant-homopteran mutualism? Insectes Sociaux 47: 84-91.

Guindon, S. \& O. Gascuel 2003. A simple, fast, and accurate algorithm to estimate large phylogenies by maximum likelihood. Systematic Biology 52: 696-704.

Gullan, P.J. 1997. Relationships with ants. In: Ben-Dov, Y. \& C.J. Hodgson (eds.) Soft Scale Insects: Their Biology, Natural Enemies and Control. Elsevier, Amsterdam: 351-373.

Gullan, P.J.\& M. Kosztarab 1997. Adaptations in scale insects. Annual Review of Entomology 42: $23-50$.

Handa, C. \& T. Itioka 2011. Effects of symbiotic coccid on the plant-ant colony growth in the myrmecophyte Macaranga bancana. Tropics 19: 139-144.

Hashimoto, Y., S. Yamane \& T. Itioka 1997 . A preliminary study on dietary habits of ants in a Bornean rain forest. Japanese Journal of Entomology 65: 688-695.

Heckroth, H.P., B. Fiala, P.J. Gullan, A.H.Idris \& U. Maschwitz 1998. The soft scale (Coccidae) associates of Malaysian ant-plants. Journal of Tropical Ecology 14: 427-443.

Heckroth, H.P., B. Fiala \& U. Maschwitz 1999. Integration of scale insects (Hemiptera: Coccidae) in the South-East Asian ant-plant (Crematogaster (Formicidae)-Macaranga (Euphorbiaceae)) system. Entomologica 33: 287-295.

Heil, M., A. Hilpert, B. Fiala \& K.E. Linsenmair 2001. Nutrient availability and indirect (biotic) defence in a Malaysian ant-plant. Oecologia 126: 404-408.

Hölldobler, B., E.O. Wilson 1990. The Ants. Belknap Press of Harvard University Press, Cambridge, MA, USA.

Huelsenbeck, J.P. \& B. Rannala 1997. Phylogenetic methods come of age: testing hypotheses in an evolutionary context. Science 276: 227-232.

Huelsenbeck, J.P. \& F. Ronquist 2001. MRBAYES: Bayesian inference of phylogenetic trees. Bioinformatics 17: 754-755.

Itino, T., S.J. Davies, H. Tada, O. Hieda, M. Inoguchi, T. Itioka, S. Yamane \& T. Inoue 2001. Cospeciation of ants and plants. Ecological Research 16: 787-793. 
Itioka, T. 2005. Diversity of anti-herbivore defenses in Macaranga. In: Roubik, D.W., S. Sakai \& A.A.H. Karim (eds.) Pollination Ecology and the Rain Forest: Sarawak Studies. Springer, New York, New York, USA, 158-171.

Itioka, T., M. Nomura, Y. Inui, T. Itino \& T. Inoue 2000. Difference in intensity of ant defense among three species of Macaranga myrmecophytes in a Southeast Asian dipterocarp forest. Biotropica 32: 318-326.

Johnson, C., D. Agosti, J.H.C. Delabie, K. Dumpert, D.J. Williams, M. von Tschirnhaus \& U. Maschwitz 2001. Acropyga and Azteca ants (Hymenoptera: Formicidae) with scale insects (Sternorrhyncha: Coccoidea): 20 million years of intimate symbiosis. American Museum Novitates 3335: 1-18.

Kato, M., T. Inoue, A.A. Hamid, T. Nagamitsu, M.B. Merdek, A.R. Nona, T. Itino, S. Yamane \& T. Yumoto 1995. Seasonality and vertical structure of light-attracted insect communities in a dipterocarp forest in Sarawak. Researches on Population Ecology 37: 59-79.

Klein, R.W., D. Kovac, A. Schellerich \& U. Maschwitz 1992. Mealybug-carrying by swarming queens of a Southeast Asian bambooinhabiting ant. Naturwissenschaften 79: 422-423.

Maschwitz,U.\&H.Hänel 1985. The migratingherdsman Dolichoderus (Diabolus) cuspidatus: an ant with a novel mode of life. Behavioral Ecology and Sociobiology 17: 171-184.

Maschwitz, U., B. Fiala, S.J. Davies \& K.E. Linsenmair 1996. A South-east Asian myrmecophyte with two alternative inhabitants: Camponotus or Crematogaster as partners of Macaranga lamellata. Ecotropica 2: 29-40.

Miller, D.R. \& M. Kosztarab 1979. Recent advances in the study of scale insects. Annual Review of Entomology 24:1-27.

Moog, J., L.G. Saw, R. Hashim \& U. Maschwitz 2005. The triple alliance: how a plant-ant, living in an ant-plant, acquires the third partner, a scale insect. Insectes Sociaux 52: 169-176.

Ozanne, C.M.P., D. Anhuf, S.L. Boulter, M. Keller, R.L. Kitching, C. Korner, F.C. Meinzer \& A.W. Mitchell 2003. Biodiversity meets the atmosphere: a global view of forest canopies. Science 301:183-186.

Posada, D. \& K.A. Crandall 1998. MODELTEST: testing the model of DNA substitution. Bioinformatics 14: 817-818.

Roubik, D.W., S. Sakai \& A.A.H. Karim (eds.) 2005. Pollination Ecology and the Rain Forest: Sarawak Studies. Springer, New York, New York, USA.

Swofford, D.L. 2002. PAUP*: phylogenetic analysis using parsimony, v. 4.0.b10. Sunderland, MA: Sinauer Associates.

Ueda, S., S.P. Quek, T. Itioka, K. Inamori, Y. Sato, K. Murase \& T. Itino 2008. An ancient tripartite symbiosis of plants, ants and scale insects. Proceedings of the Royal Society B: Biological Sciences 275: 2319-2326.

Ueda, S., S.P. Quek, T. Itioka, K. Murase \& T. Itino 2010. Phylogeography of the Coccus scale insects inhabiting myrmecophytic Macaranga plants in Southeast Asia. Population Ecology 52: 137-146. 
Ward, P.S. 1991. Phylogenetic analysis of pseudomyrmecine ants associated with domatiabearing plants. In: Huxley, C.R. \& D.F. Cutler (eds.) Ant-plant interaction. Oxford University Press, Oxford, 335-352.

Washburn, J.O. \& L. Washburn 1984. Active aerial dispersal of minute wingless arthropods: exploitation of boundary-layer velocity gradients. Science 223: 1088-1089.

Way, M.J. 1963. Mutualism between ants and honeydew-producing Homoptera. Annual Review of Entomology 8: 307-344.

Wheeler, W.M. 1921. A study of some social beetles in British Guiana and of their relations to the ant-plant Tachigalia. Zoologica 3: 35-126.

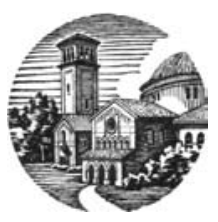

